\title{
CALCIUM BIOAVAILABILITY OF CALCIUM CARBONATE BASED DIETS FOR MALE GROWING RATS
}

Mahmoud A. Ayed

Abdullah M. Thannoun

Food Sci. \& Biotech. Dept. /Coll. of Agric. and Forestry/Mosul University- Iraq

\begin{abstract}
Calcium $(\mathrm{Ca})$ bioavailability of different levels of calcium carbonate using male Sprague-Dawley derived weanling rats was determined. Normalized value (NV), the relative bioavailability (RBV) and calcium absorption in three levels $(0.14,0.19$ and $0.24 \%)$ of three balanced diets (diets No 1, 2 and 3 ) of calcium carbonate $\left(\mathrm{CaCO}_{3}\right)$ as a source of calcium were estimated. Normalized values and RBVs in femur, tibia and fibula for rats fed diet containing $0.19 \%$ calcium (No.2) were significantly $(\mathrm{P}<0.05)$ higher $(81.8$ and $100 \%$, respectively $)$ than those $(78$; 95 and 78; 95 ) for rats fed diet containing 0.14\% (No.1) (78; 95 and 78; 95, respectively) and diet containing $0.24 \%$ calcium (No.3)(60.8; 74.2 and 60.2;73.6, respectively). Results also show that calcium absorption, total body calcium and serum calcium for rats fed diet No.2 were significantly $(\mathrm{P}<0.05)$ higher than those of rats fed diets No.1 and 3. It was concluded that calcium carbonate based diet containing $0.19 \%$ calcium with $1.5: 1$ calcium to phosphorus ratio may give high calcium bioavailability for growing rats which was considered as standard (control) diet for other diets.
\end{abstract}

\section{INTRODUCTION}

Calcium is considered as the major nutrient among macroelements and the most abundant cation in the human body accounting between 1.5-2.2 \% (Guthrie and Picciano, 1995). Calcium is very important as it plays a vital role in the human body from childhood till elderly, and it is involved in many vital functions in the body. It is an essential dietary element to maintain the integrity of skeleton and essential nutrient required in substantial amounts, but many diets are deficient in calcium making supplementation necessary or desirable (Warren Tak-Keung Lee, 1993 and Hanzlik et al., 2005). There is awareness of the importance maintaining a high calcium intake throughout the life, not just for bone health, but also for the health of other systems. However, chronic low calcium intake is associated with some health disorders and the normal ratio between calcium and phosphorus is almost constant, a little more than 2:1 (Schuette and Linkswiler, 1984 and Poneros and Erdman, 1988). Bioavailability of nutrient is the proportion of dietary nutrient which is absorbed and utilized by certain organism (O'Dell, 1984). Specifically, bioavailability of calcium from foods is an important concern because calcium intakes in our diet are quite low, and most of the calcium in food is chemically bonded to other dietary constituents, and must be released in a soluble form (Allen, 1982 and 1984). This is dependent on the composition of diets in terms of levels of dietary calcium, vitamin $\mathrm{D}$, phosphorus, magnesium, protein, fiber, phytate, fat, lactose and other sugars (Greger,1988). Calcium salts 
such as calcium carbonate, calcium sulfate, calcium citrate and Part of $\mathrm{PhD}$ Thesis of the $1^{\text {st }}$ author.

Received 2/3/2006 and accepted $10 / 5$ / 2006.

Calcium lactate are usually added to food as calcium supplements (Ranhotra et al., 1997; Martini and Wood, 2002 and Hanzlik et al., 2005). Calcium carbonate is higher in calcium than most other potential food grade calcium sources (Ranhotra et al., 1980). Rats appear to be a good model that might be developed for predicting calcium bioavailability for human being (Mahoney and Hendricks, 1985; Weaver et al., 1987 and Heaney et al., 1988). The aim of this study was to evaluate the bioavailability of calcium from basal diets fortified with different levels of calcium carbonate for rats.

\section{MATERIALS AND METHODS}

Materials: Ingredients were added to prepare the balanced diets as follows; Casein: Vitamin free casein, supplied by Riedel-Dehaen Co.Germany; Pure cellulose: Produced by Merchery Nagel and Co. Germany; Sucrose: Pure sucrose from $\mathrm{BDH}$ chemical ltd. England; Calcium carbonate $\left(\mathrm{CaCO}_{3}\right)$ : Supplied by Riedel-Dehaen Co. Germany; Starch; Corn starch, purchased from local market produced in Holland; Oil: Corn oil, purchased from local market produced in Turkey.

Balanced diets preparation: Three basal diets of calcium carbonate were prepared according to the NAS/NRC (1978) (Table 1). The diets were prepared to contain three levels of calcium $0.15,0.20$, and $0.25 \%$. Each diet contained $12 \%$ protein, $10 \%$ fat, $10 \%$ sucrose, $5 \%$ cellulose, $2 \%$ vitamins and $1.2 \%$ minerals mixtures. All dry ingredients with corn oil were weighed and mixed, and then the weight was completed with starch to make $100 \mathrm{~g}$. They were mixed again till they became homogenous and kneaded electrically in a dough mixer with addition of deionized distilled water. They were formulated; finger shaped of about $5 \mathrm{~g}$. each piece, spread in large stainless steel trays and dried in a cabinet drier at 50C for 12 hours, then packed in plastic bags and kept frozen for determinations (Table 2).

Table (1): Diets formulation $(\mathrm{g} / 100 \mathrm{~g})$.

\begin{tabular}{|c|c|c|c|c|c|c|c|c|c|}
\hline \multirow{2}{*}{$\begin{array}{l}\text { Diet } \\
\text { No. }\end{array}$} & \multirow{2}{*}{$\begin{array}{c}\mathrm{Ca} \\
\text { level } \\
\%\end{array}$} & \multirow[t]{2}{*}{$\mathrm{CaCO} 3$} & \multicolumn{7}{|c|}{ Ingredie } \\
\hline & & & Casein & $\begin{array}{c}\text { Corn } \\
\text { oil }\end{array}$ & Sucrose & Cellulose & $\begin{array}{c}\text { Minerals } \\
\text { mix }^{1}\end{array}$ & $\begin{array}{c}\text { Vitamins } \\
\text { mix }^{2}\end{array}$ & Starch \\
\hline 1 & 0.15 & 0.375 & 12.77 & 10 & 10 & 5 & 1.2 & 2 & 58.65 \\
\hline 2 & 0.20 & 0.500 & 12.77 & 10 & 10 & 5 & 1.2 & 2 & 58.53 \\
\hline 3 & 0.25 & 0.625 & 12.77 & 10 & 10 & 5 & 1.2 & 2 & 58.40 \\
\hline
\end{tabular}

1The vitamins mixture was prepared $(\mathrm{g} / \mathrm{kg})$ as follows: alpha-tocopherol $50 \mathrm{~g}$, inositol $5.0 \mathrm{~g}$, menadione $1.25 \mathrm{~g}$, vitamin A concentrate $4.5 \mathrm{~g}$, retinyl acetate 200,000 I.U., vitamin D concentrate $0.25 \mathrm{~g}$ calciferol $400.000 \mathrm{I}$.U., niacin $4.5 \mathrm{~g}$, riboflavin $1.0 \mathrm{~g}$, pyridoxine- $\mathrm{HCl} 1.0 \mathrm{~g}$, thiamine- $\mathrm{HCl} 1.0 \mathrm{~g}$, ascorbic acid $45.0 \mathrm{~g}$, pantothenate $30.0 \mathrm{~g}$, biotin $0.02 \mathrm{~g}$, folic acid $0.09 \mathrm{~g}$, and vitamin B12 0.00135g. The weight was completed to $1 \mathrm{~kg}$ by adding starch.

2 The minerals mixture was prepared $(\mathrm{g} / \mathrm{kg})$ as follows: 
$\mathrm{KCl} 296.7 \mathrm{~g}, \mathrm{MnSO}_{4} . \mathrm{H}_{2} \mathrm{O} 12.7 \mathrm{~g}, \mathrm{CoCO}_{3} .6 \mathrm{H}_{2} \mathrm{O} 0.7 \mathrm{~g}, \mathrm{MgCO}_{3} 121.0 \mathrm{~g}, \mathrm{CuSO}_{4} 1.6 \mathrm{~g}, \mathrm{KI} 0.8 \mathrm{~g}$, $\mathrm{Na}_{2} \mathrm{MoO}_{4} .2 \mathrm{H}_{2} \mathrm{O} 0.1 \mathrm{~g}, \mathrm{ZnSO} 4.7 \mathrm{H}_{2} \mathrm{O} 28.0 \mathrm{~g}, \mathrm{FeSO}_{4} .7 \mathrm{H}_{2} \mathrm{O} 30.0 \mathrm{~g}$. The weight was completed to 1 $\mathrm{kg}$ by adding starch.

Table (2): Diet composition (g/100g)

\begin{tabular}{|c|c|c|c|c|c|c|c|c|c|c|c|}
\hline \multirow{2}{*}{$\begin{array}{c}\mathrm{Ca} \\
\text { level } \\
\%\end{array}$} & \multicolumn{8}{|c|}{ Ingredients } & \multirow{2}{*}{$\begin{array}{l}\mathrm{Ca} / \mathrm{P} \\
\text { ratio }\end{array}$} & \multirow[t]{2}{*}{ Kcal } & \multirow[t]{2}{*}{$\mathrm{pH}$} \\
\hline & Moisture & Protein & Fat & Fiber & Ash & $\mathrm{CHO}^{*}$ & $\mathrm{Ca}$ & $\mathrm{P}$ & & & \\
\hline 0.15 & 12.1 & 11.88 & 9.90 & 4.85 & 1.82 & 59.45 & 0.14 & 0.14 & $1: 1$ & 376 & 5.7 \\
\hline 0.20 & 11.1 & 11.82 & 9.80 & 5.10 & 1.84 & 60.34 & 0.19 & 0.13 & $1.5: 1$ & 376 & 5.9 \\
\hline 0.25 & 12.2 & 11.86 & 10.0 & 5.00 & 1.80 & 59.14 & 0.24 & 0.12 & $2: 1$ & 376 & 5.7 \\
\hline
\end{tabular}

*by difference Values are means of three determinations.

Experimental animals: Weanling male Sprague-Dawley rats derived rats (ministry of health, Baghdad) were housed individually in suspended mesh bottom and front stainless steel hanging cages of 25 X22 X $20 \mathrm{~cm}$ ( fecal collection trays underneath ) in a controlled condition, between $20-25^{\circ} \mathrm{C}, 12$ hours light and dark cycle . After two days adaptation period, these animals were weighed and divided into 4 groups of five animals each with no statistical differences. They were fed calcium carbonate diets for 28 days. One group of five rats was sacrificed on day zero to obtain baseline animals tissues and endogenous organs for calcium determination. Animals were fed daily, their food intake was increased gradually, deionized distilled water was offered ad libitum. Animals were weighed weekly, feces were collected daily for each individual rat for the entire four weeks period, air dried, finely ground and stored for calcium and phosphorus determinations. At the end of feeding period (28 days) the animals were anesthetized (using ether); 2 $\mathrm{ml}$ of blood were withdrawn by cardiac puncture. The clotted blood was centrifuged 8 minutes to obtain serum for calcium analysis. Rats were killed and the left tibia \& fibula and left femur were removed, weighed and cleaned from adhesive tissues then soaked in hexane then ether to remove fat (Poneros and Erdman, 1989) dried and saved for calcium and phosphorus determinations. Also, liver, heart, kidneys and spleen were removed, weighed, packed in plastic bags then frozen for calcium and phosphorus determination. The carcasses were placed in a heat-resistant glass jars with addition of $25 \mathrm{ml}$ glacial acetic acid and $125 \mathrm{ml}$ deionized distilled water. The glass jars were autoclaved for 120 minutes at pressure 1 atmosphere and $121 \mathrm{C}$. The carcasses were blended and sampled for calcium and phosphorus (total body) determination.

Chemical analysis: Moisture and ash were determined according to the methods of AOAC (1980). Protein (Macrokjeldahl method), fat (Soxhlet method) and fiber were determined according to the methods mentioned by Pearson (1976). pH was determined according to the methods mentioned by Pearson (1976) and Ling (1963) using pH meter ( Philips, England ). 
Calcium determination: Calcium was determined according to the method mentioned by Pearson (1976) using flame photometer with the following modifications:

(A): Standard calcium stock solution: Transfer $2.497 \mathrm{~g}$ of $\mathrm{CaCO}_{3}$ to 1 liter volumetric flask using $100 \mathrm{ml}$ of deionized distilled water and slowly adds $60 \mathrm{ml}$ of $\mathrm{M}$ hydrochloric acid. When the $\mathrm{CaCO}_{3}$ has dissolved it was diluted to the mark with water $(1 \mathrm{ml}=1 \mathrm{mg} \mathrm{Ca})$

(B): Standard working solutions: Many dilutions were prepared from solution (A) to contain $5,10,15,20,25,30,35,40,45$ and $50 \mathrm{ppm}$ of calcium. Calcium concentrations were conducted using flame photometer apparatus, type Corning 400 , England. The mean of three readings was plotted for each dilution against calcium concentration.

(C): Calcium determination in the samples: A suitable quantity of sample was ashed in muffle furnace (AOAC, 1980), moisten by deionized distilled water in a porcelain crucible and carefully $10 \mathrm{ml}$ of $6 \mathrm{M}$ hydrochloric acid were added. Samples were evaporated to dryness on a water bath and continue the heating for a further half hour. The samples were cooled and $20 \mathrm{ml}$ of water and $10 \mathrm{ml}$ of the hydrochloric acid were added then boiled and filtered using 42 whatman filter paper into $100 \mathrm{ml}$ volumetric flask and the volume was made up to $100 \mathrm{ml}$. Solutions were kept in Stoppard polyethylene $50 \mathrm{ml}$ bottles till determination.

Phosphorus determination: Phosphorus was determined colorimetrically by Vanado-Molybdate colorimetric method after ashing samples by muffle furnace at 550C (Pearson, 1976 and AOAC, 1980) using spectrophotometer type CECIL (England) at wave length $470 \mathrm{~nm}$.

Biochemical determinations: Serum calcium: Animals were anesthetized by ether in a jar. Two $\mathrm{ml}$ of blood were withdrawn by cardiac puncture using a medical syringe. The clotted blood was centrifuged at medium speed for 8 minutes in Karl Kolb centrifuge. Serum was withdrawn using a minisyringe then diluted 1: 100 with $1 \% \mathrm{LaCl}_{3} .7 \mathrm{H}_{2} \mathrm{O}$. Standard curve of $\mathrm{CaCO}_{3}$ was plotted using $1 \%$ $\mathrm{LaCl}_{3} .7 \mathrm{H}_{2} \mathrm{O}$ by the same modified procedure as in standard curve of calcium determination. Readings were taken by flame photometer.

Hemoglobin determination (HB): Hemoglobin concentration was measured ( $\mathrm{g} /$ dl) according to Sahli method which was described in Jain (1986) by withdrawal of 20 microliter of blood in a capillary tube.

Calculations: Apparent calcium absorption was calculated as follows:

$$
\text { Consumed } \mathrm{Ca}(\mathrm{g}) \text { - fecal calcium }(\mathrm{g})
$$

Apparent calcium absorption $\%=$

Consumed $\mathrm{Ca}(\mathrm{g})$

Apparent calcium absorption (diet)

Relative apparent calcium absorption $\%=$ X 100

Apparent calcium absorption (control)

Normalized (NV) and Relative bioavailability values (RBV) were calculated as 
follows:

Total calcium in bone $(\mathrm{mg})$

$\mathrm{NV}=$

Calcium consumed $(\mathrm{g})$

NV (diet)

RBV $\%=\frac{}{\text { NV (control diet) }} \times 100$

Dry matter absorption (DMA) was calculated as follows:

Diet consumed $(\mathrm{g})$ - feces $(\mathrm{g})$

DMA $\%=\longrightarrow$ X 100

Diet consumed $(\mathrm{g})$

On dry weight basis.

Protein efficiency ratio (PER) was calculated as follows:

Body weight gain, $g$

PER $=\frac{\text { Consumed protein, } g}{\text { B }}$

Energy consumed (Kcal) was determined according to diet digestion factors in the body according to Atwater factors (Al-Zuhayri, 2000)

Statistical analysis :The data were analyzed statistically by complete randomized design using Duncan's multiple range test for means comparison on probability of $\mathrm{P}<0.05$ ( Steel and Torrie, 1980 ) and using SAS Program (1989).

\section{RESULTS AND DISCUSSION}

The nutritional status of rats fed calcium carbonate based diets is shown in Table (3). The results show that there were significant differences $(\mathrm{P}<0.05)$ in the body weight gain $(86.2 \mathrm{~g})$ of the rats in respect to calcium carbonate diet containing $0.19 \%$ calcium (No. 2). The average increase in the weight of rats fed diet containing $0.14 \%$ calcium (No.1) was $79.8 \mathrm{~g}$, while for rats fed diet containing $0.24 \%$ calcium (No.3); it was 80.0 g. Ranhotra et al. (1980) mentioned that growth of rats can be an indicator of absorbing and retention of calcium. Protein efficiency ratio (PER) can be an indicator of growth which combined with body weight gain and the protein intake. PER in rats fed diet No.2 was very close to that in rats fed carbonate diet containing $0.24 \%$ calcium at 2.19 and 2.86, respectively. This result was higher than that mentioned by Al-Qubati (2003) which was 2.16 but it was closer to our finding in the first group which fed carbonate diet containing $0.14 \%$, it was 2.27 . This result may be due to low calcium content in the diet for the first group (No.1) compared to other two groups fed calcium carbonate (diet No.2 and 3). Previously, Boelter and Greenberg (1941) mentioned that calcium content in rat's diets as low as $0.01 \%$ caused growth retardation due to the lack of diet consumption. Insignificant statistical differences $(\mathrm{P}<0.05)$ were found (Table 3) among the weights of endogenous organs (liver, heart, kidneys and spleen) of rats fed diets fortified with calcium carbonate as source of calcium. The average weights of livers for rats fed diets No. 1, 2 and 3 were 4.42, 3.97 and 
3.84g respectively; which were lower than those values found in our laboratory under similar conditions (Al- Rawashdeh, 1997). Heart weight for rats fed the three diets were all similar $(0.45 \mathrm{~g})$ but higher than that value $(0.39 \mathrm{~g})$ mentioned by Al- Rawashdeh ( 1997 ) while kidneys weight in our study were lower than that value $(1.03 \mathrm{~g})$ found by Al-Rawashdeh (1997). On the other hand, spleen weight in all three groups of rats were higher $(0.35 \mathrm{~g})$ than that found by Al-Rawashdeh (1997). Almost, similar results for rats were found by Sharaf (1998) under the same conditions. Hemoglobin values in rats fed calcium carbonate diets were close to each other and within normal value; they were 13.60, 13.02 and $13.07 \mathrm{~g} / \mathrm{dl}$ 
Table (3): Nutritional status of growing rats fed calcium carbonate based diets.

\begin{tabular}{|c|c|c|c|c|c|c|c|c|c|c|c|}
\hline \multirow{2}{*}{$\begin{array}{l}\text { Diet } \\
\text { No. }\end{array}$} & \multirow{2}{*}{$\begin{array}{c}\mathrm{Ca} \\
\text { Level } \\
\%\end{array}$} & \multirow{2}{*}{$\begin{array}{c}\text { Diet } \\
\text { Consumed } \\
\mathrm{g}\end{array}$} & \multirow{2}{*}{$\begin{array}{c}\text { Energy } \\
\text { Consumed } \\
\text { Kcal }\end{array}$} & \multicolumn{2}{|c|}{ Body Weight g } & \multirow[t]{2}{*}{ PER* } & \multirow[t]{2}{*}{$\mathrm{Hb} \mathrm{g} / \mathrm{dl}$} & \multicolumn{4}{|c|}{ Endogenous Organs g } \\
\hline & & & & $\begin{array}{l}\text { Initial } \\
\text { Weigh }\end{array}$ & $\begin{array}{c}\text { Weight } \\
\text { Gain }\end{array}$ & & & Liver & Heart & Kidneys & Spleen \\
\hline 1 & 0.14 & 297 & 1116 & $\begin{array}{c}43.0 \\
\mathrm{a}\end{array}$ & $\begin{array}{c}79.8 \pm 2.77 \\
b\end{array}$ & $\begin{array}{c}2.27 \pm 0.09 \\
b\end{array}$ & $\begin{array}{c}13.60 \pm 0.15 \\
\mathrm{a}\end{array}$ & $\begin{array}{c}4.42 \pm 0.65 \\
\mathrm{a}\end{array}$ & $\begin{array}{c}0.69 \pm 0.05 \\
\mathrm{a}\end{array}$ & $\begin{array}{c}0.69 \pm 0.05 \\
\mathrm{a}\end{array}$ & $\begin{array}{c}0.45 \pm 0.05 \\
\mathrm{a}\end{array}$ \\
\hline 2 & 0.19 & 250 & 941 & $\begin{array}{c}43.2 \\
\mathrm{a}\end{array}$ & $\begin{array}{c}86.2 \pm 3.56 \\
\mathrm{a}\end{array}$ & $\begin{array}{c}2.90 \pm 0.12 \\
\mathrm{a}\end{array}$ & $\begin{array}{c}13.02 \pm 0.10 \\
b\end{array}$ & $\begin{array}{c}3.97 \pm 0.60 \\
a\end{array}$ & $\begin{array}{c}0.45 \pm 0.06 \\
\mathrm{a}\end{array}$ & $\begin{array}{c}0.68 \pm 0.07 \\
\mathrm{a}\end{array}$ & $\begin{array}{c}0.43 \pm 0.08 \\
\mathrm{a}\end{array}$ \\
\hline 3 & 0.24 & 236 & 888 & $\begin{array}{c}41.6 \\
\mathrm{a}\end{array}$ & $\begin{array}{c}80.0 \pm 3.67 \\
b\end{array}$ & $\begin{array}{c}2.86 \pm 0.18 \\
\mathrm{a}\end{array}$ & $\begin{array}{c}13.07 \pm 0.35 \\
b\end{array}$ & $\begin{array}{c}3.84 \pm 0.52 \\
\mathrm{a}\end{array}$ & $\begin{array}{c}0.45 \pm 0.0 .05 \\
\mathrm{a}\end{array}$ & $\begin{array}{c}0.63 \pm 0.03 \\
\mathrm{a}\end{array}$ & $\begin{array}{c}0.37 \pm 0.02 \\
\mathrm{a}\end{array}$ \\
\hline
\end{tabular}

* PER $=$ Protein Efficiency Ratio. $\mathrm{Hb}=$ Hemoglobin. Values are means of five growing rats

Means sharing the same superscript letter within a column are not significantly different $(\mathrm{P}<0.05)$

Table (4): Calcium bioavailability of calcium carbonate based diets for growing rats.

\begin{tabular}{|c|c|c|c|c|c|c|c|c|c|c|c|c|c|c|}
\hline \multirow{2}{*}{$\begin{array}{l}\text { Diet } \\
\text { No. }\end{array}$} & \multirow{2}{*}{$\begin{array}{c}\mathrm{Ca} \\
\%\end{array}$} & \multirow{2}{*}{$\begin{array}{c}\text { Body Wt } \\
\text { Gain g }\end{array}$} & \multirow{2}{*}{$\begin{array}{c}\mathrm{Ca} \\
\text { Consumed } \\
\mathrm{g}\end{array}$} & \multicolumn{4}{|c|}{ Tibia \& Fibula bones } & \multicolumn{4}{|c|}{ Femur bone } & \multicolumn{3}{|c|}{ Tibia, Fibula \& Femur } \\
\hline & & & & Weight $\mathrm{g}$ & Ca mg & $\mathrm{NV}^{1}$ & $\begin{array}{c}\mathrm{RBV}^{2} \\
\%\end{array}$ & Weight g & Ca mg & NV & $\begin{array}{c}\mathrm{RBV} \\
\%\end{array}$ & Weight g & $\mathrm{Ca} \mathrm{mg}$ & $\begin{array}{c}\mathrm{RBV} \\
\%\end{array}$ \\
\hline 1 & 0.14 & $\begin{array}{c}79.8 \pm 2.77 \\
b\end{array}$ & $\begin{array}{c}0.41 \pm 0.01 \\
\mathrm{c}\end{array}$ & $\begin{array}{c}0.22 \pm 0.01 \\
\mathrm{a}\end{array}$ & $\begin{array}{c}32.5 \pm 1.6 \\
b\end{array}$ & $\begin{array}{c}78.0 \pm 4.3 \\
\mathrm{a}\end{array}$ & $\begin{array}{c}95.0 \\
b\end{array}$ & $\begin{array}{c}0.22 \pm 0.01 \\
\mathrm{a}\end{array}$ & $\begin{array}{c}32.5 \pm 2.0 \\
b\end{array}$ & $\begin{array}{c}78.0 \pm 4.8 \\
\mathrm{a}\end{array}$ & $\begin{array}{c}95.0 \\
\mathrm{a}\end{array}$ & $\begin{array}{c}0.44 \pm 0.02 \\
\mathrm{a}\end{array}$ & $\begin{array}{c}65.0 \pm 3.2 \\
b\end{array}$ & $\begin{array}{c}95.0 \\
\mathrm{a}\end{array}$ \\
\hline 2 & 0.19 & $\begin{array}{c}86.2 \pm 3.56 \\
a\end{array}$ & $\begin{array}{c}0.47 \pm 0.01 \\
b\end{array}$ & $\begin{array}{c}0.23 \pm 0.01 \\
\mathrm{a}\end{array}$ & $\begin{array}{c}38.9 \pm 2.1 \\
\mathrm{a}\end{array}$ & $\begin{array}{c}81.8 \pm 3.7 \\
\mathrm{a}\end{array}$ & $\begin{array}{c}100 \\
\mathrm{a}\end{array}$ & $\begin{array}{c}0.24 \pm 0.02 \\
\mathrm{a}\end{array}$ & $\begin{array}{c}38.4 \pm 3.2 \\
\mathrm{a}\end{array}$ & $\begin{array}{c}81.6 \pm 4.1 \\
\mathrm{a}\end{array}$ & $\begin{array}{c}100 \\
\mathrm{a}\end{array}$ & $\begin{array}{c}0.47 \pm 0.04 \\
\mathrm{a}\end{array}$ & $\begin{array}{c}77.8 \pm 4.9 \\
\mathrm{a}\end{array}$ & $\begin{array}{c}100 \\
\mathrm{a}\end{array}$ \\
\hline 3 & 0.24 & $\begin{array}{c}80.0 \pm 3.67 \\
b\end{array}$ & $\begin{array}{c}0.56 \pm 0.01 \\
\mathrm{a}\end{array}$ & $\begin{array}{c}0.22 \pm 0.01 \\
\mathrm{a}\end{array}$ & $\begin{array}{c}34.4 \pm 1.4 \\
\text { b }\end{array}$ & $\begin{array}{c}60.8 \pm 2.5 \\
b\end{array}$ & $\begin{array}{c}74.2 \\
c\end{array}$ & $\begin{array}{c}0.22 \pm 0.01 \\
\mathrm{a}\end{array}$ & $\begin{array}{c}34.2 \pm 1.2 \\
\text { b }\end{array}$ & $\begin{array}{c}60.2 \pm 1.9 \\
b\end{array}$ & $\begin{array}{c}73.6 \\
b\end{array}$ & $\begin{array}{c}0.44 \pm 0.01 \\
\mathrm{a}\end{array}$ & $\begin{array}{c}68.6 \pm 2.5 \\
b\end{array}$ & $\begin{array}{c}73.8 \\
b\end{array}$ \\
\hline $\mathrm{BL}^{*}$ & -- & -- & -- & $\begin{array}{c}0.08 \pm 0.01 \\
b\end{array}$ & $\begin{array}{c}9.4 \pm 0.74 \\
c\end{array}$ & -- & -- & $\begin{array}{c}0.08 \pm 0.01 \\
b\end{array}$ & $\begin{array}{c}9.8 \pm 0.2 \\
\mathrm{c}\end{array}$ & -- & -- & $\begin{array}{c}0.16 \pm 0.01 \\
b\end{array}$ & $\begin{array}{c}19.2 \pm 0.8 \\
c\end{array}$ & -- \\
\hline
\end{tabular}

Values are means of five animals.

Means sharing the same superscript letter within a column are not significantly different $(\mathrm{P}<0.05)$ 
for rats fed carbonate diets no. 1, 2, and 3 respectively. Sharaf (1998) mentioned that hemoglobin for rats were between 12.32 to $12.34 \mathrm{~g} / \mathrm{dl}$. Al-Qubati (2003) also, found hemoglobin values in rats between 12.70 to $13.50 \mathrm{~g} / \mathrm{dl}$ under similar conditions. However, these results were lower than that $(14.80 \mathrm{~g} / \mathrm{dl})$ for the rats published by Ralston Purina Company (1984).

Results in Table (4) show calcium bioavailability for growing rats fed diets containing different levels of calcium carbonate. Data show that calcium consumption by the animals was increased with increasing the level of calcium carbonate in the diets. Insignificant differences $(\mathrm{P}<0.05)$ were found among weight of tibia for the three groups of rats fed different levels of calcium carbonate diets. Weights of tibia were ranged between 0.22 to $0.23 \mathrm{~g}$ but total calcium of tibia and femur for rats fed diet No. 2 was higher than those fed diet No.1 and 3. Calcium percent for these treatments were 16.9 and $16.0 \%$, respectively. Ranhotra et al. (1997) found that femur calcium content of growing rats was 17.1 $\%$ which fed bread diet fortified with $\mathrm{CaCO}_{3}$. Tibia and femur calcium contents for baseline animals were 11.7 and $12.2 \%$, respectively which were higher than that (10.7 \% femur calcium content) mentioned by Ranhotra et al. (1997). Normalized values were significantly $(\mathrm{P}<0.05)$ low in rats fed diet No.3 comparing to those fed diets No.1 and 2. The result may be due to the amounts of calcium consumed which lead to reduce absorption efficiency. This result was also in agreement with those conducted by Behling and Greger (1990). In human, Heaney et al. (1990) found that absorption of calcium was $64 \%$ by women subjects fed small amounts of calcium but it was $28.6 \%$ when the amount of ingested calcium increased. Bone calcium content and calcium absorption data can be a good indicator to assess relative bioavailability of calcium in rats (Ranhotra et al., 1980 and 1997). Tibia calcium content was utilized as an indicator of calcium bioavailability since it reflects calcium retention by rats (Heaney, 1986). Rats fed diet No. 2 containing $0.19 \%$ calcium can be a control (standard) group according to normalized value which was higher than other groups (NV was $81.8 \mathrm{mg}$ calcium per $\mathrm{g}$ of tibia). So, bioavailability arbitrarily set at $100 \%$ for rats fed $\mathrm{CaCO}_{3}$ diet containing $0.19 \%$ calcium. RBV for rats fed diets No. 1 and 3 were $95.0 \%$ and $74.2 \%$, respectively. Table (4) also revealed femur weights for the three rat groups fed $\mathrm{CaCO}_{3}$ diets, were between 0.22 to $0.24 \mathrm{~g}$ with no significant differences. Femur calcium in rats fed calcium carbonate diet containing $0.19 \%$ calcium was significantly $(\mathrm{P}<0.05)$ higher comparing with other groups, therefore, there is higher NV for this treatment which was $81.6 \mathrm{mg} / \mathrm{g}$. This result was very close to NV in tibia for the same group, while NV in tibia and fibula for animals fed diets No.1 and No.3 were 78.0 and 60.8, respectively. These results were very close to NV in femur for the same groups (78.0 and 60.2, respectively). It was concluded that rat group fed diet No. 2 considered as control group according to calcium content of tibia and femur, in which, RBV in this group was higher $(100 \%)$ than others (95\% and $73.8 \%$ for rats fed diet No.1 and 3, respectively). The result may be due to predominance of active transport of calcium in intestinal 
tract more than diffusion transport under low levels of dietary calcium comparing with the results of Poneros and Erdman (1989).

Table (5) shows calcium absorption in growing rats fed calcium carbonate diets. Fecal calcium were $0.20,0.17$ and $0.22 \mathrm{~g}$ for rats fed diets No.1, 2 and 3 which were containing $0.14,0.19$ and $0.24 \%$, respectively .It was known that upon higher calcium absorption there was lower fecal calcium (Ranhotra et al. 1997). Fecal calcium was high $(0.22 \mathrm{~g})$ in rats consumed higher amount of calcium $(0.56 \mathrm{~g})$ in rats fed diet No. 3. It was concluded that with increasing calcium consumption more calcium was loss in the feces therefore, decreasing calcium absorption (Behling and Greger, 1990 and Heaney et al. 1990). The results show that apparent absorption in group No.2 was $62.6 \%$ while it was 51.0 and $60.6 \%$ in group fed diets No.1 and 3, respectively which means higher absorption efficiency of calcium in rats fed diet containing $0.19 \%$ calcium compared to other groups. Ranhotra et al. (1997) referred that apparent absorption of calcium in rats was higher when consumed calcium amount at marginal level. Relative apparent absorption for rats fed diet No.1 and No.3 were 81.2 and 96.8 $\%$, respectively comparing to control group (No.2). Ranhotra et al. (1997) found that the relative apparent absorption ranged between 94.6 to $98.0 \%$ in growing rats fed bread diet fortified with calcium carbonate, sulfate, citrate and lactate. Many factors increase fecal calcium such as high content of fat in diet and or the presence of some substances e. g. oxalate, phytate or fibers (Allen, 1982; Turnlund, 1987; Weaver et al.1987 and Guthrie and Picciano, 1995). No significant differences $(\mathrm{P}<0.05)$ were found among dry matter absorption ( DMA $\%$ ) for rats fed diets No.1, 2 and 3, they were 91.8, 92.0 and $91.6 \%$, respectively. This result may be due to the similarity of ingredients of the diets. Similar result of DMA for rats was found by Behling and Greger (1990) in their study on mature female rats fed similar levels of dietary salts.

Table (6) shows body calcium profile and endogenous organs of the rats .Calcium contents of liver, heart, kidneys and spleen for rats fed diet No.2 were 8.3, 13.8, 15.5 and $20.8 \mathrm{mg}$ calcium per gram of each organ, respectively. Calcium content of these organs was higher than those for rats fed diets No.1 and 3. The calcium content of endogenous organs for rats fed diet No.1 was as follows: 8.0,13.0, 14.2 and $19.8 \mathrm{mg} / \mathrm{g}$ of liver, heart, kidneys and spleen, respectively. In rats fed diet No.3 calcium content in these organs were $7.9,13.0,14.8$ and $19.5 \mathrm{mg} / \mathrm{g}$ at the same order. This data confirmed what had mentioned earlier about calcium content in tibia and femur and emphasize that rats fed diet No. 2 was control group. Total body calcium was $1.90,1.94$ and $1.89 \%$ for rats fed diets No.1, 2 and 3, respectively. Group fed diet No.2 showed the highest (1.94\%) of calcium may be due to balanced ratio between calcium and phosphorus in the diet (1.5: 1) (Guthrie and Picciano, 1995 and Al-Zuhayri, 2000). Insignificant differences $(\mathrm{P}<0.05)$ in the average initial body weight of baseline animals $(43.0 \mathrm{~g}$ ) comparing with the body weight of the rats in tested groups fed $\mathrm{CaCO}_{3}$ diets. Weight of liver, heart, kidneys and spleen for baseline animals were 2.52, 0. 27, 0.52 and $0.08 \mathrm{~g}$, respectively. Calcium content of these organs was significantly $(\mathrm{P}<0.05)$ lower comparing with those for animals grown up on $\mathrm{CaCO}_{3}$ diets for 28 days (Table 6). The amounts of calcium in liver, 
heart, kidneys and spleen of this group found to be 5.7, 7.1, 7.4 and $10.9 \mathrm{mg} 1 \mathrm{~g}$, respectively, while total calcium in the whole body was $1.61 \%$, this result was significantly $(\mathrm{P}<0.05)$ lower than those for other animals which fed carbonate diets.

Table (7) shows calcium and phosphorus interaction and their absorption in growing rats. Results show that rats fed diet No.1 consumed $0.41 \mathrm{~g}$ of each calcium and phosphorus (ratio 1: 1 ), the other group fed diet No .2, consumed $0.47 \mathrm{~g}$ of calcium and $0.32 \mathrm{~g}$ of 
Table (5); Calcium absorption of calcium carbonate based diets for growing rats.

\begin{tabular}{|c|c|c|c|c|c|c|c|c|c|}
\hline \multirow{2}{*}{$\begin{array}{l}\text { Diet } \\
\text { No. }\end{array}$} & \multirow{2}{*}{$\begin{array}{c}\mathrm{Ca} \\
\text { level } \\
\%\end{array}$} & \multicolumn{2}{|c|}{ Body weight g } & \multirow{2}{*}{$\begin{array}{c}\text { Diet } \\
\text { Consumed } \\
\mathrm{g}\end{array}$} & \multirow{2}{*}{$\begin{array}{c}\mathrm{Ca} \\
\text { consumed } \\
\mathrm{g}\end{array}$} & \multirow{2}{*}{$\begin{array}{l}\text { Feces } \\
\text { Ca g }\end{array}$} & \multirow{2}{*}{$\begin{array}{c}\mathrm{Ca} \\
\text { absorption } \\
\%\end{array}$} & \multirow{2}{*}{$\begin{array}{l}\text { Relative Ca } \\
\text { absorption }\end{array}$} & \multirow{2}{*}{$\begin{array}{c}\text { Dry matter } \\
\text { absorption } \%\end{array}$} \\
\hline & & Initial & Gain & & & & & & \\
\hline 1 & 0.14 & 43.0 & $79.8 \pm 2.77 \mathrm{~b}$ & 297 & $0.41 \pm 0.01 \mathrm{c}$ & $0.20 \mathrm{~b}$ & $51.0 \pm 3.93 \mathrm{~b}$ & $81.2 \pm 6.41 \mathrm{~b}$ & $91.8 \pm 0.54 \mathrm{a}$ \\
\hline 2 & 0.19 & 43.2 & $86.2 \pm 3.56 \mathrm{a}$ & 250 & $0.41 \pm 0.01 b$ & $0.17 \mathrm{c}$ & $62.6 \pm 1.14 \mathrm{a}$ & $100.0 \mathrm{a}$ & $92.0 \pm 0.44 \mathrm{a}$ \\
\hline 3 & 0.24 & 41.6 & $80.0 \pm 3.67 \mathrm{~b}$ & 236 & $0.56 \pm 0.01 \mathrm{a}$ & $0.22 \mathrm{a}$ & $60.6 \pm 2.19 \mathrm{a}$ & $96.8 \pm 3.49 \mathrm{a}$ & $91.6 \pm 1.00 \mathrm{a}$ \\
\hline
\end{tabular}

Values are means of five animals. $\quad$ Means sharing the same superscript letter within a column are not significantly different $(\mathrm{P}<0.05)$.

Table (6): Calcium profile of body tissues of growing rats fed calcium carbonate based diets.

\begin{tabular}{|c|c|c|c|c|c|c|c|c|c|c|c|c|}
\hline \multirow{3}{*}{$\begin{array}{l}\text { Diet } \\
\text { No. }\end{array}$} & \multirow{3}{*}{$\begin{array}{c}\mathrm{Ca} \\
\text { level } \\
\%\end{array}$} & \multirow{3}{*}{$\begin{array}{l}\text { Body } \\
\text { weight } \\
\text { gain g }\end{array}$} & \multirow{3}{*}{$\begin{array}{c}\mathrm{Ca} \\
\text { consumed } \\
\mathrm{g}\end{array}$} & \multicolumn{8}{|c|}{ Endogenous organs } & \multirow{3}{*}{$\begin{array}{c}\text { Total } \\
\text { body } \\
\text { calcium } \\
\%\end{array}$} \\
\hline & & & & \multicolumn{2}{|c|}{ Liver } & \multicolumn{2}{|c|}{ Heart } & \multicolumn{2}{|c|}{ Kidneys } & \multicolumn{2}{|c|}{ Spleen } & \\
\hline & & & & Weight g & $\mathrm{Ca} \mathrm{mg/g}$ & Weight g & $\mathrm{Ca} \mathrm{mg/g}$ & Weight g & $\mathrm{Ca} \mathrm{mg/g}$ & Weight $\mathrm{g}$ & $\mathrm{Ca} \mathrm{mg/g}$ & \\
\hline 1 & 0.14 & $\begin{array}{c}79.8 \pm 2.77 \\
b\end{array}$ & $\begin{array}{c}0.41 \pm 0.01 \\
\mathrm{c}\end{array}$ & $\begin{array}{c}4.42 \pm 0.65 \\
\mathrm{a}\end{array}$ & $\begin{array}{c}8.0 \pm 0.63 \\
\mathrm{a} \\
\end{array}$ & $\begin{array}{c}0.45 \pm 0.06 \\
\mathrm{a}\end{array}$ & $\begin{array}{c}13.0 \pm 0.44 \\
b\end{array}$ & $\begin{array}{c}0.69 \pm 0.05 \\
\mathrm{a}\end{array}$ & $\begin{array}{c}14.2 \pm 0.52 \\
\mathrm{c}\end{array}$ & $\begin{array}{c}0.45 \pm 0.05 \\
\mathrm{a}\end{array}$ & $\begin{array}{c}19.8 \pm 0.25 \\
b\end{array}$ & $1.90 \pm 0.01$ \\
\hline 2 & 0.19 & $\begin{array}{c}86.2 \pm 3.56 \\
a\end{array}$ & $\begin{array}{c}0.41 \pm 0.01 \\
\mathrm{~b}\end{array}$ & $\begin{array}{c}3.97 \pm 0.60 \\
\mathrm{a} \\
\end{array}$ & $\begin{array}{c}8.3 \pm 0.29 \\
a\end{array}$ & $\begin{array}{c}0.45 \pm 0.06 \\
\mathrm{a} \\
\end{array}$ & $\begin{array}{c}13.8 \pm 0.33 \\
\mathrm{a} \\
\end{array}$ & $\begin{array}{c}0.68 \pm 0.07 \\
\mathrm{a} \\
\end{array}$ & $\begin{array}{c}15.5 \pm 0.31 \\
\mathrm{a} \\
\end{array}$ & $\begin{array}{c}0.43 \pm 0.08 \\
\mathrm{a} \\
\end{array}$ & $\begin{array}{c}20.8 \pm 0.74 \\
\mathrm{a} \\
\end{array}$ & $\begin{array}{c}1.94 \pm 0.01 \\
\mathrm{a}\end{array}$ \\
\hline 3 & 0.24 & $\begin{array}{c}80.0 \pm 3.67 \\
b\end{array}$ & $\begin{array}{c}0.56 \pm 0.01 \\
\mathrm{a}\end{array}$ & $\begin{array}{c}3.84 \pm 0.52 \\
\mathrm{a}\end{array}$ & $\begin{array}{c}7.9 \pm 0.20 \\
a \\
\end{array}$ & $\begin{array}{c}0.45 \pm 0.05 \\
\mathrm{a}\end{array}$ & $\begin{array}{c}13.0 \pm 0.23 \\
b\end{array}$ & $\begin{array}{c}0.63 \pm 0.03 \\
\mathrm{a}\end{array}$ & $\begin{array}{c}14.8 \pm 0.32 \\
b\end{array}$ & $\begin{array}{c}0.37 \pm 0.02 \\
\mathrm{a}\end{array}$ & $\begin{array}{c}19.5 \pm 0.21 \\
b\end{array}$ & $\begin{array}{c}1.89 \pm 0.02 \\
b\end{array}$ \\
\hline $\mathrm{BL}^{*}$ & -- & -- & -- & $\begin{array}{c}2.52 \pm 0.38 \\
b\end{array}$ & $\begin{array}{c}5.7 \pm 0.04 \\
b\end{array}$ & $\begin{array}{c}0.27 \pm 0.04 \\
b\end{array}$ & $\begin{array}{c}7.1 \pm 0.42 \\
\mathrm{c}\end{array}$ & $\begin{array}{c}0.52 \pm 0.05 \\
b\end{array}$ & $\begin{array}{c}7.4 \pm 0.15 \\
\mathrm{~d}\end{array}$ & $\begin{array}{c}0.08 \pm 0.01 \\
b\end{array}$ & $\begin{array}{c}10.9 \pm 0.50 \\
\mathrm{c}\end{array}$ & $\begin{array}{c}1.61 \pm 0.01 \\
\mathrm{c}\end{array}$ \\
\hline
\end{tabular}

* Baseline animals. Values are means of five animals. Means sharing the same superscript letter within a column are not significantly different $(\mathrm{P}<0.05)$.

Table (7): Calcium and phosphorus interaction and their absorption in growing rats fed calcium carbonate based diets.

\begin{tabular}{|c|c|c|c|c|c|c|c|c|c|c|c|c|c|c|}
\hline \multirow{2}{*}{$\begin{array}{l}\text { Diet } \\
\text { No. }\end{array}$} & \multirow{2}{*}{$\begin{array}{c}\text { Body } \\
\text { weight } \\
\text { gaing }\end{array}$} & \multirow{2}{*}{$\begin{array}{c}\mathrm{Ca} \\
\text { consumed } \\
\mathrm{g}\end{array}$} & \multirow{2}{*}{$\begin{array}{c}\mathrm{P} \\
\text { consumed } \\
\mathrm{g}\end{array}$} & \multirow[t]{2}{*}{$\mathrm{Ca} / \mathrm{P}$} & \multicolumn{2}{|c|}{ Tibia \&Femur } & \multirow{2}{*}{$\begin{array}{c}\text { Serum Ca } \\
\mathrm{mg} / \mathrm{dl}\end{array}$} & \multirow{2}{*}{$\begin{array}{c}\text { Feces Ca } \\
\mathrm{g}\end{array}$} & \multirow{2}{*}{$\begin{array}{c}\mathrm{Ca} \\
\text { absorption } \\
\%\end{array}$} & \multirow{2}{*}{$\begin{array}{c}\text { Fecal P } \\
\mathrm{g}\end{array}$} & \multirow{2}{*}{$\begin{array}{c}\mathrm{P} \\
\text { absorption } \\
\%\end{array}$} & \multirow{2}{*}{$\begin{array}{c}\% \\
\text { DMA }\end{array}$} & \multicolumn{2}{|c|}{ Total Body } \\
\hline & & & & & Ca mg & $\mathrm{P} \mathrm{mg}$ & & & & & & & $\mathrm{Ca} \%$ & $\mathrm{P} \%$ \\
\hline 1 & $\begin{array}{c}123 \pm 4.2 \\
\mathrm{~b}\end{array}$ & $\begin{array}{c}0.41 \pm 0.01 \\
\mathrm{c}\end{array}$ & $\begin{array}{c}0.41 \pm 0.01 \\
\mathrm{a}\end{array}$ & $1: 1$ & $\begin{array}{c}65.0 \pm 3.2 \\
b\end{array}$ & $\begin{array}{c}33.9 \pm 1.5 \\
\mathrm{a}\end{array}$ & $\begin{array}{c}8.6 \pm 0.29 \\
b\end{array}$ & $\begin{array}{c}0.20 \pm 0.01 \\
b\end{array}$ & $\begin{array}{c}51.0 \pm 3.9 \\
b\end{array}$ & $\begin{array}{c}0.15 \pm 0.01 \\
\mathrm{a}\end{array}$ & $\begin{array}{c}63.0 \pm 0.79 \\
\mathrm{a}\end{array}$ & $\begin{array}{c}92 \pm 0.5 \\
\mathrm{a}\end{array}$ & $\begin{array}{c}1.9 \pm 0.01 \\
b\end{array}$ & $\begin{array}{c}0.88 \pm 0.01 \\
\mathrm{a}\end{array}$ \\
\hline 2 & $\begin{array}{c}129 \pm 5.3 \\
\mathrm{a}\end{array}$ & $\begin{array}{c}0.47 \pm 0.01 \\
b\end{array}$ & $\begin{array}{c}0.32 \pm 0.01 \\
b\end{array}$ & $1: 1.5$ & $\begin{array}{c}77.8 \pm 4.9 \\
\mathrm{a}\end{array}$ & $\begin{array}{c}34.5 \pm 4.6 \\
\mathrm{a}\end{array}$ & $\begin{array}{c}10.1 \pm 0.30 \\
\mathrm{a}\end{array}$ & $0.17 \pm 0.01 \mathrm{c}$ & $\begin{array}{c}62.6 \pm 1.1 \\
\mathrm{a}\end{array}$ & $\begin{array}{c}0.11 \pm 0.01 \\
b\end{array}$ & $\begin{array}{c}65.1 \pm 0.96 \\
\mathrm{a}\end{array}$ & $\begin{array}{c}92 \pm 0.4 \\
\mathrm{a}\end{array}$ & $\begin{array}{c}1.9 \pm 0.01 \\
\mathrm{a}\end{array}$ & $\begin{array}{c}0.88 \pm 0.01 \\
\mathrm{a}\end{array}$ \\
\hline 3 & $\begin{array}{c}122 \pm 4.0 \\
b\end{array}$ & $\begin{array}{c}0.56 \pm 0.01 \\
\mathrm{a}\end{array}$ & $\begin{array}{c}0.28 \pm 0.01 \\
\mathrm{c}\end{array}$ & $1: 2$ & $\begin{array}{c}68.6 \pm 2.5 \\
b\end{array}$ & $\begin{array}{c}28.4 \pm 2.9 \\
b\end{array}$ & $\begin{array}{c}8.2 \pm 0.38 \\
b\end{array}$ & $0.22 \pm 0.01 \mathrm{a}$ & $\begin{array}{c}60.6 \pm 2.2 \\
a\end{array}$ & $\begin{array}{c}0.11 \pm 0.01 \\
b\end{array}$ & $\begin{array}{c}59.4 \pm 1.40 \\
b\end{array}$ & $\begin{array}{c}92 \pm 1.0 \\
\mathrm{a}\end{array}$ & $\begin{array}{c}1.89 \pm 0.02 \\
b\end{array}$ & $\begin{array}{c}0.81 \pm 0.08 \\
b\end{array}$ \\
\hline
\end{tabular}

DMA= Dry Matter Absorption. Values are means of five animals. 
Means sharing the same superscript letter within a column are not significantly different $(\mathrm{P}<0.05)$. 
phosphorus ( ratio $1.5: 1$ ), while the rats fed diet No. 3, consumed 0.56 and $0.28 \mathrm{~g}$ of each of calcium and phosphorus respectively( ratio $2: 1$ ). Calcium phosphate plays an important role in bone formation in which $90 \%$ of phosphorus found in the body in the form of calcium phosphate (Hydroxyapatite) in bones and teeth and bone calcification is affected when the ratio between calcium and phosphorus in blood is unbalanced (Williams, 1985). Dietary recommended amounts of phosphorus represented 2: 3 of calcium.

recommended amounts, this ratio is similar to the ratio of these elements in human milk and similar to their ratio in bones (Williams, 1985 and Guthrie and Picciano, 1995). Total calcium content in tibia and femur was $77.8 \mathrm{mg}$ in rats fed diet No.2. This result was significantly $(\mathrm{P}<0.05)$ high comparing to rats fed $\mathrm{CaCO}_{3}$ diets No. 1 and 3 which contain 65.0 and $68.6 \mathrm{mg}$, respectively. Concerning phosphorus bioavailability, tibia and femur of rats fed $\mathrm{CaCO}_{3}$ diet No. 2 retained $34.5 \mathrm{mg}$ of phosphorus, while in rats fed diet No.1 and 3 phosphorus amounts were 33.928 .4 $\mathrm{mg}$, respectively . Calcium absorption depends on the ratio between calcium and phosphorus in diet, if the ratio less than 2: 1 in adults or less than 1: 1 in some categories e.g. children, or nutrition during pregnancy or nutrition of growing animals. It has been known that the amount of absorbed calcium decreases due to interference in sites of absorption. The ratio of calcium to phosphorus in human body is 2: 1 , whereas the optimum ratio of calcium to phosphorus in diet is $(1.5: 1)$ for more calcium absorption (Williams, 1985 and Al-Zuhayri, 2000). The results in Table (7) show that low amount of fecal calcium was indicated and high calcium absorption for rats fed diet No. 2 which consumed calcium to phosphorus ratio of 1.5: 1. Fecal calcium in this group was $0.17 \mathrm{~g}$ which significantly $(\mathrm{P}<0.05)$ differed as compared to rats fed $\mathrm{CaCO}_{3}$ diets No.1 and 3 in which the calcium lost in feces were 0.20 and 0.22 , respectively. Serum calcium in rats fed carbonate diets No.1, 2 and 3 were 8.6, 10.1 and $8.2 \mathrm{mg} / \mathrm{dl}$, respectively, all in the normal limit. Ranhotra et al. (1997) found that serum calcium in growing rats was 6 - $12 \mathrm{mg} / \mathrm{dl}$. Ralston Purina Company (1984) referred that serum calcium level in rats was $12.4 \mathrm{mg} / \mathrm{dl}$. Serum can be constant parameter to predict the response toward minerals e. g. calcium (Wood, 2000). Weaver et al. (2002) determined calcium in Asian women by appearance of $\mathrm{Ca}^{45}$ in serum. Apparent absorption of calcium was 51.0, 62.6 and $60.6 \%$ for rats fed diets No.1, 2 and 3, respectively. Fecal phosphorus amounts were $0.15,0.11$ and $0.11 \mathrm{mg}$ for rats fed diets No. 1, 2 and 3 ,respectively, as a result the apparent absorption of phosphorus were 63.0, 65.1 and $59.4 \%$, respectively. The higher apparent absorption of phosphorus was in rats fed diet No.2 with calcium to phosphorus ratio of 1.5: 1. It has been known that this ration is preferable (Williams, 1985 and Al-Zuhayri, 2000). Dry matter absorption (DMA \%) for rats fed diets No.1, 2 and 3 were $91.8,92.0$ and $91.6 \%$, respectively. The results show that there were no significant differences $(\mathrm{P}<0.05)$ between the values, however, higher DMA\% was found in rats fed diet No. 2. Whole body calcium in rats fed diet No.2 was $1.94 \%$ , it was significantly $(\mathrm{P}<0.05)$ higher than that of other groups, while whole body 
phosphorus was similar in rats fed diets No.1 and $2(0.88 \%)$ but significantly $(\mathrm{P}<0.05)$ decreased in rats fed diet No $.3(0.81 \%)$. 
Mesopotamia J. of Agric. $\quad$ (ISSN 1815-316X) $\quad$ Vol. (34) No. (2) 2006

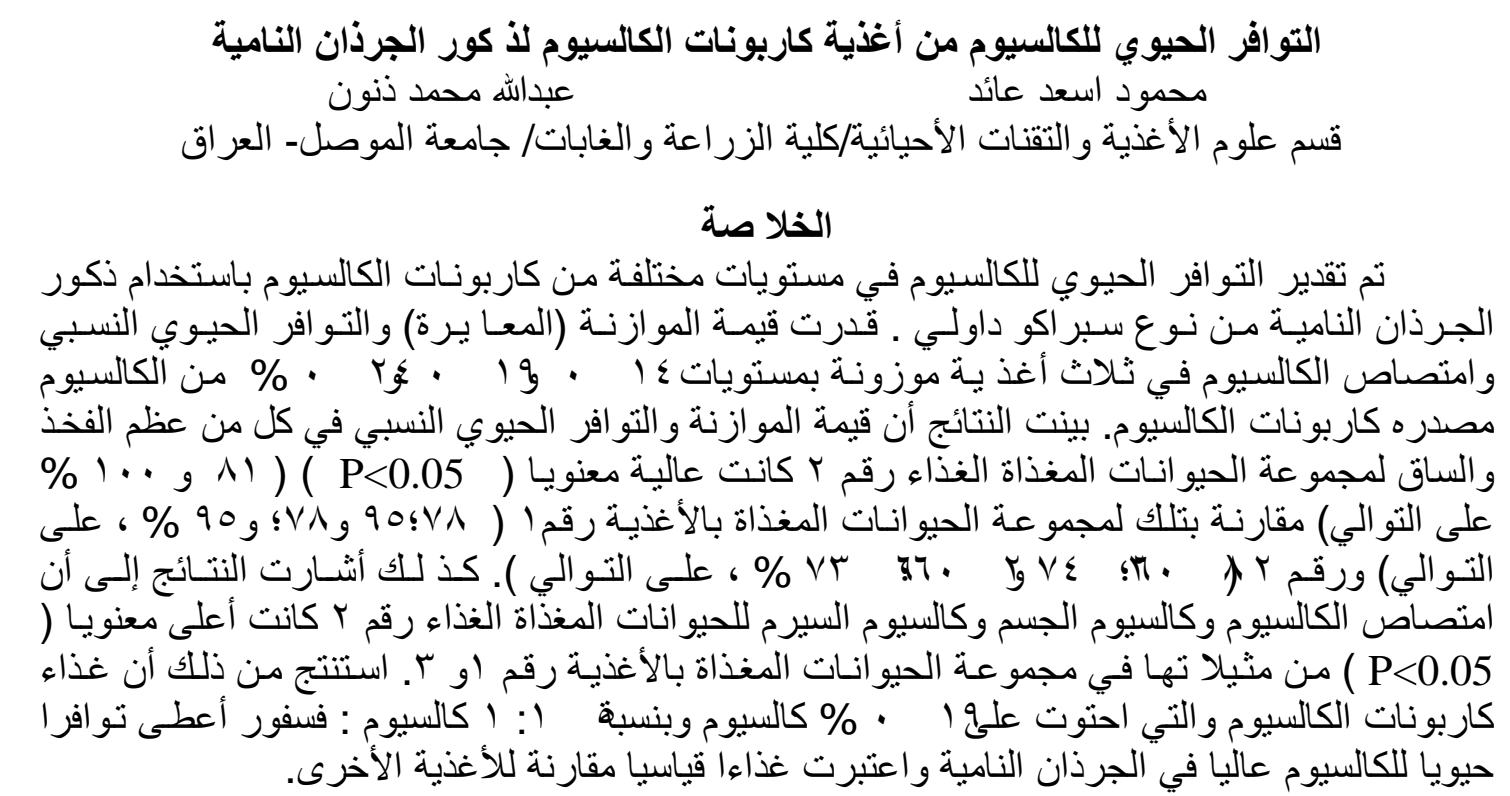

\section{REFERENCES}

Al-Qubati, A. M. M. (2000). Processing and evaluation of some complimentary infant formulas.M. Sc. Thesis. Mosul University, Iraq.

Al-Qubati, A. M. M. (2003). Glycemic index of some foods. Ph.D. Thesis. Mosul University, Iraq.

Allen, L.H. (1982). Calcium bioavailability and absorption: a review. Am. J. Clin. Nutr., 35: 783-808.

Allen L. H. (1984).Calcium absorption and requirments during the life span. Nutr.News 47:1-3.

Al-Rawashdeh, A.Y. (1997). Cholesterol and body lipid profile of growing male rats fed oils, fats and their mixtures. Ph.D. Thesis. Mosul University, Iraq.

Al-Zuhayri, A. M. T. (2000). Human Nutrition. $2^{\text {nd }}$ Ed Dar Al-kutub for printing and publishing, Mosul University, Iraq.

Association of Official Analytical Chemists (AOAC) (1980). Official methods of analysis, $13^{\text {th }}$ Ed., Washington, DC.

Behling, A.R. and J.L. Greger (1990). Importance of lactose in yogurt for mineral utilization. J. Agric. Food Chem. 38(1): 200-204.

Greger, J. L. (1988). Calcium Bioavailability. Cereal Food World 33:796-799.

Gueguen, L. and A. Pointillart (2000). The bioavailability of dietary calcium. J. Am. Coll. Nutr. 19(2): 136S-199S.

Guthrie, H.A. and M.F. Picciano (1995). Human nutrition p. 303-331 WCB/McGrawHill Co. USA.

Hanzlik, R.P.; S.C. Fowler and D.H. Fisher (2005). Relative bioavailability of calcium from calcium formata, calcium citrate and calcium carbonate. J. Pharmac. Exp. Ther. 313(3): 1217-1222.

Heaney, R.P. (1986). Calcium bioavailability. Contemporary Nutrition Vol. 11 No. 8.

Heaney, R.P.; C.M. Weaver and R.R. Recker (1988). Calcium absorbability from spinach. Am. J. Clin. Nutr. 47: 707-709.

Heaney, R.P.; R.R. Recker and C.M. Weaver (1990). Absorbability of calcium sources: The limited role of solubility. Calcif. Tissue Int. 46: 300-304. 
Jain, N.C. (1986). Schalms veterinary hematology. p.267-282. Lea and Febiger, USA..

Ling, E.R. (1963). A textbook of dairy chemistry, Vol. 2 Practical, Chapman and Hall Ltd. London.

Looker, A.C.; R.R. Briefel and M.A. McDowell (1994). Calcium intake in the US. Optimal calcium intake. NIH consensus development conference. p. 19-21 Bethesda, MD.

Mahoney, A. W. and D. G. Hendricks (1984). Potential of the rat as a model for predicting iron bioavailability for human. Nutr. Res. 4: 913-922.

Martini, L. and R.J. Wood (2002). Relative bioavailability of calcium-rich dietary sources in the elderly. AJCN 76(6):1345-1350.

National Academy of Science-National Research Council (NAS/NRC) (1978). Nutrient requirements of laboratory animals. $3^{\text {rd }}$ Ed. No. 10. Washington, DC.

O’Dell, B.L. (1984). Bioavailability of trace elements. Nutr. Rev. 42: 301.

Pearson, D. (1976). The Chemical Analysis of Foods. $7^{\text {th }}$ Ed. Churchill Livingstone, Edinburgh, London and New York

Poneros, A.G. and J.W. Erdman J.R. (1988). Bioavailability of calcium from tofu, tortillas, non fat dry milk and mozzarella cheese in rats: effect of supplemental ascorbic acid. J. Food Science 53(1): 208-210.

Poneros, A.G. and J.W. Erdman J.R. (1989). Bioavailability of calcium sesame seeds, almond powder, whole wheat bread, spinach and non fat dry milk. J. Food Sci. 54(1): 150-153.

Ralston Purina Company (1984). The lab facts book. Lab Chows, the control factor. Ralston Purina Company Publishers. USA.

Ranhotra, G.S.; C. Lee and J. Gelorth (1980). Expanded cereal fortification: Bioavailability and functionality (bread making) of various calcium sources. Nutr. Rep. Int. 22(4):469-475

Ranhotra, G.S.; J.A. Gelorth; S.D. Leinen and F.E. Schneller (1997). Bioavailability of calcium in breads fortified with different calcium sources. Cereal Chem. 74(4): 361-363.

SAS Version (1989). Statistical Analysis System. SAS Institute Inc. SAS/Stat guide for personal computer. Cary, NC, USA.

Schuette, S.A. and H.M. Linkswiler (1984). Calcium. In nutrition reviews, present knowledge in nutrition. $5^{\text {th }}$ Ed. P. 400-412. The nutrition foundation, Inc. Washington, DC.

Sharaf, Kh. H. (1998). Iron bioavailability of meat, legumes and leafy vegetables for anemic and healthy rats. Ph.D. Thesis. Mosul University, Iraq.

Steel, R.G.D. and J.H. Torrie (1980). Principles and Procedures of Statistics. McGrawHill Book co., Inc., New York.

Turnlund, J.R. (1987). Carbohydrate, fiber and mineral interactions. In nutrition 87 levander, O.A. ed. P. 73-40 American Institute of nutrition, Bethesda, MD.

Warren Tak-Keung Lee (1993). Requirements of calcium: are there ethnic differences ? Asian Pacific J. Clin. Nutr. 2: 183-190.

Weaver, C.M.; R.P. Heaney; L. Connor; B.R. Martin; D.L. Smith and S. Nielsen (2002). Bioavailability of calcium from tofu as compared with milk in premenopausal women. J. Food Science 67(8): 3144-3147.

Williams, S.R. (1985). Nutrition and Diet Therapy. $5^{\text {th }}$ Ed. The C.V. Mosby Company. St. Louis. 
Wood, R. J. (2000). Calcium and phosphorus. In Biochemical and Physiological Aspects of Human Nutrition Ed. By Martha H. Stipanuk. W. B. Saunders Company, Philadelphia, USA.. 